\title{
Barley yellow dwarf virus and Cereal yellow dwarf virus Quantification by Real-Time Polymerase Chain Reaction in Resistant and Susceptible Plants
}

\author{
Boovaraghan Balaji, Dennis B. Bucholtz, and Joseph M. Anderson
}

First author: Department of Agronomy, 915 West State Street, Purdue University, West Lafayette, IN 47907; and second and third authors: Crop Production and Pest Control Research, U.S. Department of Agriculture-Agricultural Research Service, Department of Agronomy, 915 West State Street, Purdue University, West Lafayette, IN 47907. Accepted for publication 13 May 2003.

\begin{abstract}
Balaji, B., Bucholtz, D. B., and Anderson, J. M. 2003. Barley yellow dwarf virus and Cereal yellow dwarf virus quantification by real-time polymerase chain reaction in resistant and susceptible plants. Phytopathology 93:1386-1392.

Reliable detection and quantification of barley and cereal yellow dwarf viruses (YDVs) is a critical component in managing yellow dwarf diseases in small grain cereal crops. The method currently used is enzyme-linked immunosorbent assay (ELISA), using antisera against the coat proteins that are specific for each of the various YDVs. Recently, quantitative real-time reverse-transcription polymerase chain reaction (Q-RT-PCR) has been used to detect bacterial and viral pathogens and to

genes because of the higher sensitivity of RT-PCR and the advantage of using a real-time PCR instrument. This Q-RT-PCR was used to detect BYDV and CYDV, and to examine disease development in a resistant wheatgrass, a resistant wheat line, a susceptible wheat line, and a susceptible oat line. BYDV-PAV and CYDV-RPV were detected as early as 2 and $6 \mathrm{~h}$, respectively, in susceptible oat compared with detection by ELISA at 4 and 10 days postinoculation. BYDV-PAV RNA accumulated more rapidly and to a higher level than CYDV-RPV RNA in both oat and wheat, which may account for PAV being more prevalent and causing more severe viral disease than CYDV. Q-RT-PCR is reproducible, sensitive, and has the potential to be used for examining yellow dwarf disease and as a rapid diagnostic tool for YDVs.
\end{abstract} study gene expression. We applied this technique to detect and quantify YDVs using primers specific for Barley yellow dwarf virus-PAV (BYDV$\mathrm{PAV}$ ) and Cereal yellow dwarf virus-RPV (CYDV-RPV) coat protein
Additional keywords: luteovirus, polerovirus.
Yellow dwarf viruses (YDVs) are a group of luteo- and poleroviruses that are obligately transmitted by aphids and are the most economically important viral pathogens of cereal grains (15). YDVs cause an average of 5 to $10 \%$ yield loss annually (6), with wheat losses in the United States estimated at 2 to $10 \%$ on a regional basis (21). In 2002, losses in the Midwestern United States were estimated to be 10 to $20 \%$ (H. Ohm, personal communication). Perry et al. (22) demonstrated that, in wheat, the level of Barley yellow dwarf virus (BYDV) infection in field plots was directly correlated with yield loss. It is clear from these results that BYDV and Cereal yellow dwarf virus (CYDV) can have a significant impact on cereal grain production.

Following the demonstration that several wheatgrass species are highly resistant to infection by YDVs (27), various laboratories are actively engaged in research to incorporate resistance into wheat, barley, and oat through interspecific crosses. Components of this resistance have been successfully transferred into wheat (29). A wheat line (P29) was developed in which the 7D chromosome was substituted with a group 7 chromosome from the wheatgrass Thinopyrum intermedium (28). The level of resistance in this line was determined by enzyme-linked immunosorbent assay (ELISA) (2), which showed that the titer of the BYDV strain, P-PAV (Purdue isolate of virus transmitted by Rhopalosiphum

Corresponding author: J. M. Anderson; E-mail address: jmanders@purdue.edu

Publication no. P-2003-0922-01R

This article is in the public domain and not copyrightable. It may be freely reprinted with customary crediting of the source. The American Phytopathological Society, 2003. padi Linn. and by Macrosiphum avenae Fabr.) in leaf and stem tissue was significantly reduced (42 to 52\%) compared with the control line. Wheat line P29 also showed complete resistance to CYDV-NY-RPV (New York isolate of virus transmitted by $R$. padi) (2).

Our objective in the present study was to obtain a more thorough understanding of YDV accumulation in both resistant and susceptible cereal species. We have done this by using quantitative real-time reverse-transcription polymerase chain reaction (Q-RT-PCR) to determine the relative amount of BYDV and CYDV RNA after inoculation in the resistant substitution wheat line (P29), a susceptible wheat line (8138), a susceptible oat line (Clintland 64), and a resistant wheatgrass (Thinopyrum intermedium cv. Oahe). Quantification of YDV infection in cereal crops is usually done by ELISA using either the double-antibody sandwich (DAS) or triple-antibody sandwich (TAS) technique $(25,26)$. Both of these methods are time consuming and involve the use of expensive antisera. When compared with ELISA, RTPCR is more sensitive and, consequently, can detect a lower viral titer in plants $(13,18,20)$. The higher sensitivity of RT-PCR has been demonstrated by the ability of this technique to detect YDV in individual aphids (5). Recently, Q-RT-PCR was introduced to quantify gene transcripts precisely and reproducibly (12). This method monitors fluorescence emitted during the reaction as an indicator of the amount of amplicon produced after each PCR cycle, as opposed to the endpoint detection methods of conventional PCR. An increase in fluorescence is associated with the concentration of PCR products in the reaction. Recording the amount of fluorescence emission at the end of each cycle monitors the PCR reaction during amplification and identifies when the first significant increase in product occurs. This increase is 
directly correlated with the initial cDNA template concentration (4).

Several methods currently are available for Q-RT-PCR. In this research, we have used SYBR Green I, a double-stranded DNA binding dye, to detect and quantify BYDV and CYDV PCR products during interactions in a YDV-resistant wheatgrass and susceptible oat. The procedure described here is reproducible, sensitive, and readily shows the effect of the cereal species and its genotype on YDV RNA accumulation. This Q-RT-PCR assay also has the potential to be used as a rapid diagnostic tool for BYDVPAV and CYDV-RPV.

\section{MATERIALS AND METHODS}

Aphids and virus strains. Viruliferous aphids (R. padi Linn.) harboring both BYDV P-PAV and CYDV NY-RPV were used as the vector for transmitting the viruses to plants. Viruliferous aphids were routinely maintained on oat (Avena sativa L. cv. Clintland 64), with a third of infected plants replaced with uninfected plants every 2 weeks to ensure a steady supply of green plants for aphid feeding. Viruliferous aphids were allowed a virus acquisition access period of at least $96 \mathrm{~h}$ before they were used to inoculate test plants. Frequent verification was done by RT-PCR to check for the presence of PAV and RPV coat protein genes in the infected oat source plants.

Plant material. Two trays ( $\approx 100$ plants/tray) each of YDVsusceptible oat (A. sativa cv. Clintland 64), YDV-resistant wheatgrass (Thinopyrum intermedium cv. Oahe), YDV-resistant wheat (Triticum aestivum L.) line P29, and susceptible wheat (Triticum aestivum) line 8138 were grown in a growth chamber with a cycle of $16 \mathrm{~h}$ of light and $8 \mathrm{~h}$ of dark at $23^{\circ} \mathrm{C}$. Two trays, one of oat and one of wheatgrass, were grown to the two-leaf stage and infested with viruliferous aphids ( $R$. padi Linn.) containing both P-PAV and NY-RPV. Control trays were not infested with aphids. Aphids were allowed an inoculation access period of $3 \mathrm{~h}$ on oat and wheatgrass before being sprayed with malathion. Control plants without aphids also were uniformly sprayed with malathion. Entire plants, from the crown region upward, were harvested at 0 , $2,4,6,12,24,48$, and $96 \mathrm{~h}$ and $6,8,10$, and 12 days after spraying with insecticide. The 0 -h harvest was collected immediately after spraying insecticide. A total of six plants were collected for each harvest time point at random locations within the tray and pooled together. The resistant (P29) and susceptible (8138) wheat lines were similarly inoculated, except that an inoculation access period of $24 \mathrm{~h}$ with viruliferous aphids was used prior to spraying insecticide and plants were harvested daily for a total of 12 days. All plant tissues were immediately frozen in liquid nitrogen after harvesting and stored at $-80^{\circ} \mathrm{C}$ until further use. Tissues were ground in liquid nitrogen and the ground tissues were used for ELISA and Q-RT-PCR analysis.

ELISA. ELISA was performed according to the DAS method $(7,11)$. Optical density readings of the ELISA were measured with a microtiter plate reader (Model MR600; Dynatech Laboratories Inc., Alexandria, VA) in dual wavelength mode at 410 and $630 \mathrm{~nm}$. The $\rho$-nitrophenol chromophore was measured at $410 \mathrm{~nm}$ and plate imperfections were corrected by measuring at $630 \mathrm{~nm}$.
Plant RNA extraction and cDNA synthesis. Total RNA was extracted by TRIzol (Invitrogen Life Technologies, Carlsbad, CA) according to manufacturer's protocol. Total RNA concentration was measured with an 8452A Diode array UV-Spectrophotometer (Hewlett Packard, Palo Alto, CA) and the integrity was checked by electrophoresis in a $1.2 \%$ agarose-formaldehyde gel. Before use in RT-PCR reactions, all RNAs were treated with RNAse-free DNAse at $37^{\circ} \mathrm{C}$ for $30 \mathrm{~min}$ (Promega Corp., Madison, WI) to ensure that the RT-PCR products originated from RNA and not DNA. The RNA was incubated at $65^{\circ} \mathrm{C}$ for $15 \mathrm{~min}$ to inactivate DNAse, extracted with phenol/chloroform (24:1, vol/vol), precipitated with ethanol, and resuspended in diethyl pyrocarbonatetreated water and used as template for first-strand cDNA synthesis. For Q-RT-PCR analysis, an equivalent amount of total RNA from pairs of consecutive harvests was pooled (i.e., RNA from first and second day, third and fourth day, fifth and sixth day, and so on) and first-strand cDNA was synthesized.

First-strand cDNA synthesis was carried out using the Superscript First Strand Synthesis System for RT-PCR following the manufacturer's guidelines (Invitrogen Life Technologies). Random hexamers were used as first-strand cDNA primers instead of oligo-dT because the YDV genomes are not polyadenylated. The cDNA concentration was measured with a UV spectrophotometer to normalize the nucleic acid concentration for subsequent PCR reactions.

Real-time RT-PCR. Primers for P-PAV and NY-RPV coat proteins and 18S rRNA for internal controls were designed by using the Applied Biosystems Primer Express Software (version 1.5; Applied Biosystems, Foster City, CA) (Table 1). Primer validation experiments were performed with fivefold serial dilutions of cDNA (Fig. 1). Validation experiments were performed to demonstrate that the amplification efficiencies of target primers (P-PAV and NY-RPV coat protein) were approximately equal to the efficiency of the endogenous reference primers (18S rRNA). Briefly, real-time PCR was done with fivefold serial dilutions of a cDNA sample using P-PAV and NY-RPV coat protein and 18S rRNA primers. Once the respective cycle thresholds (Cts) were obtained at different dilutions, the $\Delta \mathrm{Ct}(\mathrm{Ct}$ of target minus $\mathrm{Ct}$ of reference) was calculated and plotted against the logarithmic value of input cDNA concentrations. The absolute value of the slope of the plot for each primer set was determined to be less than 0.1, which indicated that the amplification efficiencies of PAV, RPV, and $18 \mathrm{~S}$ rRNA primers were approximately equal (16).

Using the ABI PRISM 7700 Sequence Detection system (Applied Biosystems), the real-time RT-PCR reaction was done in a total volume of $20 \mu$ that contained SYBR Green I PCR Master Mix (Applied Biosystems), $500 \mathrm{nM}$ each of forward and reverse primers (Table 1), and $20 \mathrm{ng}$ of cDNA template. The PCR reaction was initiated with a preincubation at $50^{\circ} \mathrm{C}$ for $2 \mathrm{~min}$ and denaturation at $95^{\circ} \mathrm{C}$ for $10 \mathrm{~min}$, followed by 40 cycles of denaturation at $95^{\circ} \mathrm{C}$ for $15 \mathrm{~s}$ and annealing and extension together at $60^{\circ} \mathrm{C}$ for $1 \mathrm{~min} /$ cycle. Immediately after the final PCR cycle, a melting curve analysis was done to determine specificity of the reaction by incubating the reaction at $95^{\circ} \mathrm{C}$ for $15 \mathrm{~s}$, annealing at $60^{\circ} \mathrm{C}$ for $20 \mathrm{~s}$, and then slowly increasing the temperature to $95^{\circ} \mathrm{C}$ over $20 \mathrm{~min}$. The $\mathrm{Ct}$ used in the real-time PCR quantification is defined

TABLE 1. Oligonucleotide primers used for reverse-transcription polymerase chain reaction

\begin{tabular}{|c|c|c|c|c|}
\hline Name & Sequence $\left(5^{\prime}-3^{\prime}\right)$ & Product size $(b p)$ & $T_{m}\left({ }^{\circ} \mathrm{C}\right)^{\mathrm{a}}$ & Accession no. (reference) $)^{b}$ \\
\hline PAV-coat protein (forward) & aatgcccagcgetttcag & 91 & 79 & X17261 (31) \\
\hline PAV-coat protein (reverse) & gcggacgcgtgtgacttaa & $\ldots$ & $\ldots$ & \\
\hline RPV-coat protein (forward) & acgagttggaccccattg & 101 & 79 & $\mathrm{X} 17259(31)$ \\
\hline RPV-coat protein (reverse) & gatcatcttcgctgggaagct & $\ldots$ & $\ldots$ & \\
\hline 18S rRNA (forward) & gtgacgggtgacggagaatt & 151 & 81 & AY049040 (1) \\
\hline 18S rRNA (reverse) & gacactaatgcgeccggtat & $\ldots$ & $\ldots$ & \\
\hline
\end{tabular}

a Melting temperature $\left(T_{m}\right)$ values were used for dissociation curve analysis.

${ }^{\mathrm{b}}$ Accession number in NCBI database followed by the reference number. 
as the PCR cycle number that crosses an arbitrarily chosen signal threshold in the log phase of the amplification curve. Each cDNA was loaded in triplicate on a single 96-well plate and the PCR procedure as a whole was repeated at least twice. Relative quantification was measured using the comparative $\mathrm{Ct}\left(2^{-\Delta \Lambda C t}\right)$ method (16). In this method, the change in amount of the target genes (PPAV and NY-RPV coat protein) was normalized to the expression of the $18 \mathrm{~S}$ rRNA gene. The $2^{-\Delta \Delta \mathrm{Ct}}$ data analysis is where $\Delta \Delta \mathrm{Ct}=$ $(\mathrm{Ct} \text { of target }-\mathrm{Ct} \text { of } 18 \mathrm{~S} \text { rRNA })_{\text {Timex }}-(\mathrm{Ct}$ of target $-\mathrm{Ct}$ of $18 \mathrm{~S}$ rRNA) $)_{\text {Time1 }}$. In our experiments, Time 1 was the first time point where target gene amplification was first detected. The $\mathrm{Ct}$ at this time point was the maximum $\mathrm{Ct}$ for that target gene. The subsequent level of P-PAV and NY-RPV coat protein RNAs were determined relative to this maximum $\mathrm{Ct}$.

Cloning and sequencing. To ensure that the PCR reactions were producing the expected viral sequences, RT-PCR products were cloned into pGEM-T vector system (Promega). Approximately $10 \mathrm{ng}$ of PAV and RPV amplicon inserts were ligated to the vector at $4{ }^{\circ} \mathrm{C}$ overnight, transformed into DH5 $\alpha$ competent cells, and plated onto Luria-Bertani media containing carbenicillin at $50 \mu \mathrm{g} / \mathrm{ml}$. Colony PCR using SP6 and T7 or gene-specific primers for P-PAV and NY-RPV (10) was used to rapidly identify PCR fragment-positive colonies. The PCR conditions were $94^{\circ} \mathrm{C}$ denaturation for $10 \mathrm{~min}$ followed by 35 cycles of $94^{\circ} \mathrm{C}$ for $30 \mathrm{~s}$, $55^{\circ} \mathrm{C}$ for $30 \mathrm{~s}$, and $72^{\circ} \mathrm{C}$ for $30 \mathrm{~s}$. The PCR reaction was terminated with a final extension at $72^{\circ} \mathrm{C}$ for $7 \mathrm{~min}$. Plasmids for sequencing were isolated using QIAprep Spin Miniprep kit (Qiagen, Valencia, CA) according to the manufacturer's protocol. Cloned PCR products were sequenced using the thermosequenase fluorescent-labeled primer cycle sequencing kit with 7-diaza $\mathrm{dGTP}$ and the ALFexpress automated sequencer following the manufacturer's protocol (Amersham Pharmacia Biotech, Piscataway, NJ).
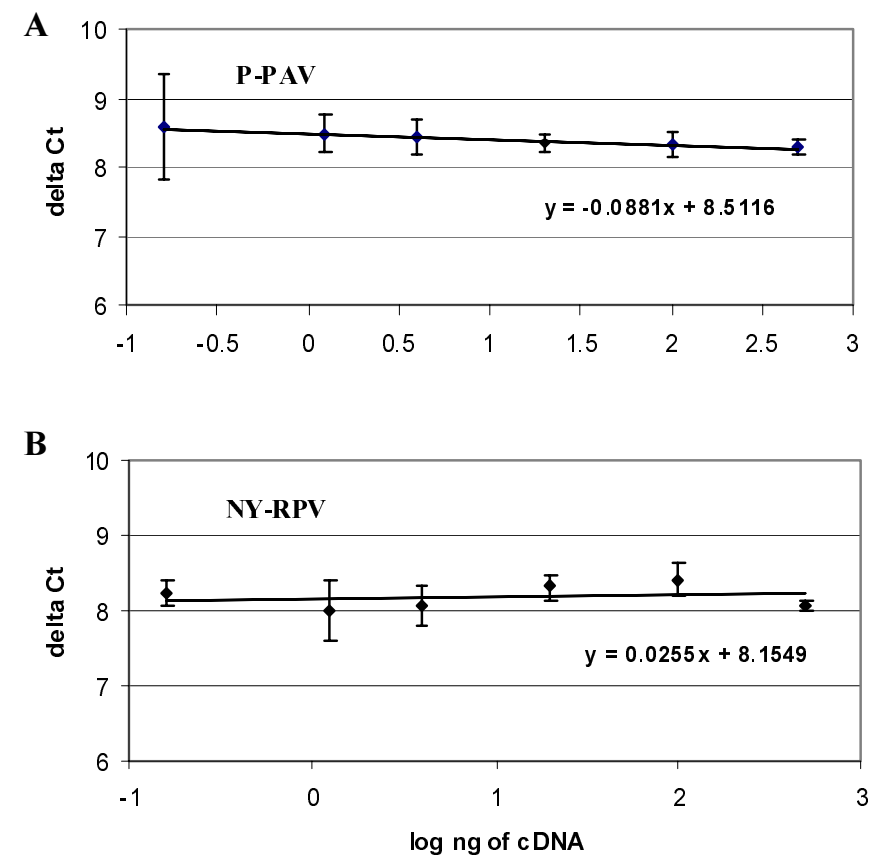

Fig. 1. Primer efficiency validation was determined using fivefold serial dilutions of cDNA that were amplified by real-time polymerase chain reaction using A, P-PAV and $\mathbf{B}$, NY-RPV coat protein-specific primers. The $18 \mathrm{~S}$ rRNA primers were used as an endogenous internal control. The $\Delta \mathrm{Ct}$ (cycle threshold [Ct] of P-PAV or NY-RPV - Ct of 18S rRNA) was plotted against the log concentration of cDNA. Because the slope for each graph was less than 0.1 , the virus coat protein gene primers were considered to have the same priming efficiency as the endogenous internal control 18S rRNA primers.

\section{RESULTS}

Amplification specificity of P-PAV and NY-RPV coat proteins. RT-PCR experiments with oat plants treated with viruliferous aphids produced the expected amplicons representing the coat protein genes of P-PAV and NY-RPV. The predicted RT-PCR product length was confirmed by agarose gel electrophoresis (data not shown). In all cases, a single fragment was amplified which was cloned and sequenced. This sequencing confirmed that the PCR products were the expected viral sequences (data not shown). Dissociation curve analysis done at the end of the real-time RTPCR also demonstrated that each of the primer pairs tested (Table 1) amplified a single PCR product with a distinct melting temperature $\left(T_{m}\right)$ (Fig. 2A and B). The fluorescence $(-\mathrm{dF} / \mathrm{dT})$ was plotted against temperature to produce a dissociation curve for each sample. Each double-stranded DNA product has its own specific $T_{m}$. Because 18S rRNA, P-PAV, and NY-RPV primer pairs each amplified products that had the same $T_{m}$, nonspecific products or primer dimers were not observed in our experiments. This demonstrated that the primers for P-PAV and NY-RPV were appropriate to use in real-time detection and quantification of virus in plants.

ELISA. To compare the virus coat protein accumulation, an ELISA was done for the oat and wheatgrass experiments. The PPAV titer began to increase from 4 days postinfestation (dpi), after which there was an appreciable increase in the titer through $10 \mathrm{dpi}$ and then a slight decline by 12 dpi (Table 2). However, the RPV titer did not show any significant increase until 8 through $12 \mathrm{dpi}$. There was no detectable P-PAV and NY-RPV titer in wheatgrass (Table 2).

Quantitative evaluation of viral replication in YDV-resistant and -susceptible plants. Utilizing the comparative $\mathrm{Ct}\left(2^{-\Delta \mathrm{Ct}}\right)$ method for relative quantification of viral RNAs required that the P-PAV and NY-RPV primers be validated with respect to the endogenous control primers, 18S rRNA. The absolute values for P-PAV and NY-RPV in this validation were 0.08 and 0.02 , respectively, which demonstrated that the efficiencies of viral and 18S rRNA amplification were nearly identical (Fig. 1A and B). The Ct of all the reactions run simultaneously, usually in a 96-well PCR plate, was determined by moving the dark horizontal line to an arbitrarily chosen point in the log phase of PCR amplification (Fig. 2C). The Cts for PAV, RPV, and 18S rRNA were used to monitor and quantify YDV replication in a resistant wheatgrass and susceptible oat line (Table 3) and resistant and susceptible wheat lines, P29 and 8138, respectively (Fig. 3).

For relative quantification of P-PAV and NY-RPV, we chose the maximum $\mathrm{Ct}$ that determined a positive detection limit. The time points where there was no detectable amplification were not considered because, at these time points, the arbitrary horizontal line to measure the $\mathrm{Ct}$ did not cross the amplification plot. P-PAV was first detected at $0 \mathrm{~h}$ postinfestation (hpi) in both the oat and wheatgrass. Consequently, in Table 3, the amounts of P-PAV RNA present at subsequent time points are relative to $0 \mathrm{hpi}$, which was set at 1 . The 0 -hpi sample was collected immediately after insecticide spraying to kill the aphids. In the experiments with oat and wheatgrass, the amount of P-PAV RNA was 11- to 32-fold higher than NY-RPV RNA in the early sampling times of 2 to 4 hpi. PPAV accumulation also was faster than that of the NY-RPV in a susceptible plant (Table 3). An 11-fold increase in P-PAV RNA occurred as early as $2 \mathrm{hpi}$, with a peak of 15,181-fold at $8 \mathrm{dpi}$ followed by a decline to 5,429-fold by the final 12 dpi. However, in ELISA, P-PAV titer was detected only after 4 dpi and increased until $8 \mathrm{dpi}$, when it reached a plateau for the remainder of the time course (Table 2). NY-RPV RNA increased more slowly than PPAV in susceptible oat; however, at $12 \mathrm{dpi}$, it was near the maximum level of P-PAV (Table 3). In a susceptible oat, NY-RPV was first detected at $4 \mathrm{hpi}$. In a resistant wheatgrass, both the P-PAV and NY-RPV RNA amounts were very low when compared with the susceptible inoculated oat. In wheatgrass, there appeared to be 
a minimal amount of P-PAV in the earlier sampling times ( 2 to $12 \mathrm{~h}$ ). This may be attributed to the presence of dead viruliferous aphids still present on the sampled leaves or a slight amount of viral replication. NY-RPV RNA was not detected in the earlier sampling times.

The results with susceptible wheat line 8138 and resistant wheat line P29 validated our findings with oat and wheatgrass (Fig. 3 and Table 3). For relative quantification of P-PAV and NY-RPV, we identified the maximum $\mathrm{Ct}$ that determined a positive detection limit, set that value to one, and calculated the fold increase or decrease relative to that. The increase in the amount of P-PAV RNA was appreciable in 8138 compared with the increase in P29. In P29, there was significantly less P-PAV RNA compared with the susceptible wheat line 8138. In this experiment, an inoculation access period of $24 \mathrm{~h}$ with viruliferous aphids was used, which is in contrast to the experiment with oat and wheatgrass, where the infestation period was $3 \mathrm{~h}$. The reason for this change in protocol was to ensure that P29 was inoculated with NY-RPV. The results obtained with wheat resembled the results observed in wheatgrass. There was a slight increase of NY-RPV RNA in P29 compared with the zero time control, which then decreased to a basal level thereafter. As in wheatgrass, it is unclear if this RPV increase is due to the presence of RPV RNA in the aphid or a low level of viral replication. These results do demonstrate that the high CYDVRPV resistance in wheatgrass was transferred to P29, whereas only partial resistance to P-PAV was transferred from wheatgrass into this wheat line.

\section{DISCUSSION}

Wheatgrass species such as Thinopyrum intermedium, Thinopyrum elongatum, Thinopyrum pulcherrimum, and Aegilops spp. have been found to be resistant to a wide array of pathogens and pests, such as YDVs $(14,27,34)$, Wheat streak mosaic virus (27),

TABLE 2. Enzyme-linked immunosorbent assay (ELISA) of yellow dwarf virus in oat and wheatgrass for P-PAV and NY-RPV after inoculation ${ }^{\mathrm{a}}$

\begin{tabular}{lccccc}
\hline & \multicolumn{2}{c}{ PAV } & & \multicolumn{2}{c}{ RPV } \\
\cline { 6 - 6 } \cline { 5 - 6 } Treatment $^{\mathrm{b}}$ & Oat & Wheatgrass & & Oat & Wheatgrass \\
\hline Time & & & & & \\
Control & 0.005 & 0.003 & & -0.006 & -0.023 \\
$0 \mathrm{~h}$ & 0.009 & 0.009 & & -0.016 & -0.019 \\
$2 \mathrm{~h}$ & 0.006 & 0.006 & & -0.014 & -0.022 \\
$4 \mathrm{~h}$ & 0.003 & 0.002 & & -0.015 & -0.024 \\
$6 \mathrm{~h}$ & 0.008 & -0.002 & & -0.014 & -0.025 \\
$12 \mathrm{~h}$ & 0.002 & -0.004 & & -0.016 & -0.024 \\
$24 \mathrm{~h}$ & 0.003 & 0.004 & & -0.02 & -0.026 \\
2 days & 0.004 & 0.002 & -0.019 & -0.026 \\
4 days & 0.385 & 0.011 & -0.017 & -0.025 \\
6 days & 1.078 & 0.017 & & 0.021 & -0.027 \\
8 days & 1.580 & 0.003 & & 0.08 & -0.025 \\
10 days & 1.757 & 0.003 & & 0.523 & -0.025 \\
12 days & 1.574 & -0.002 & 0.526 & -0.024 \\
\hline
\end{tabular}

${ }^{a}$ ELISA values were the average of two readings.

$\mathrm{b}$ Time postinfestation; control = no aphid.
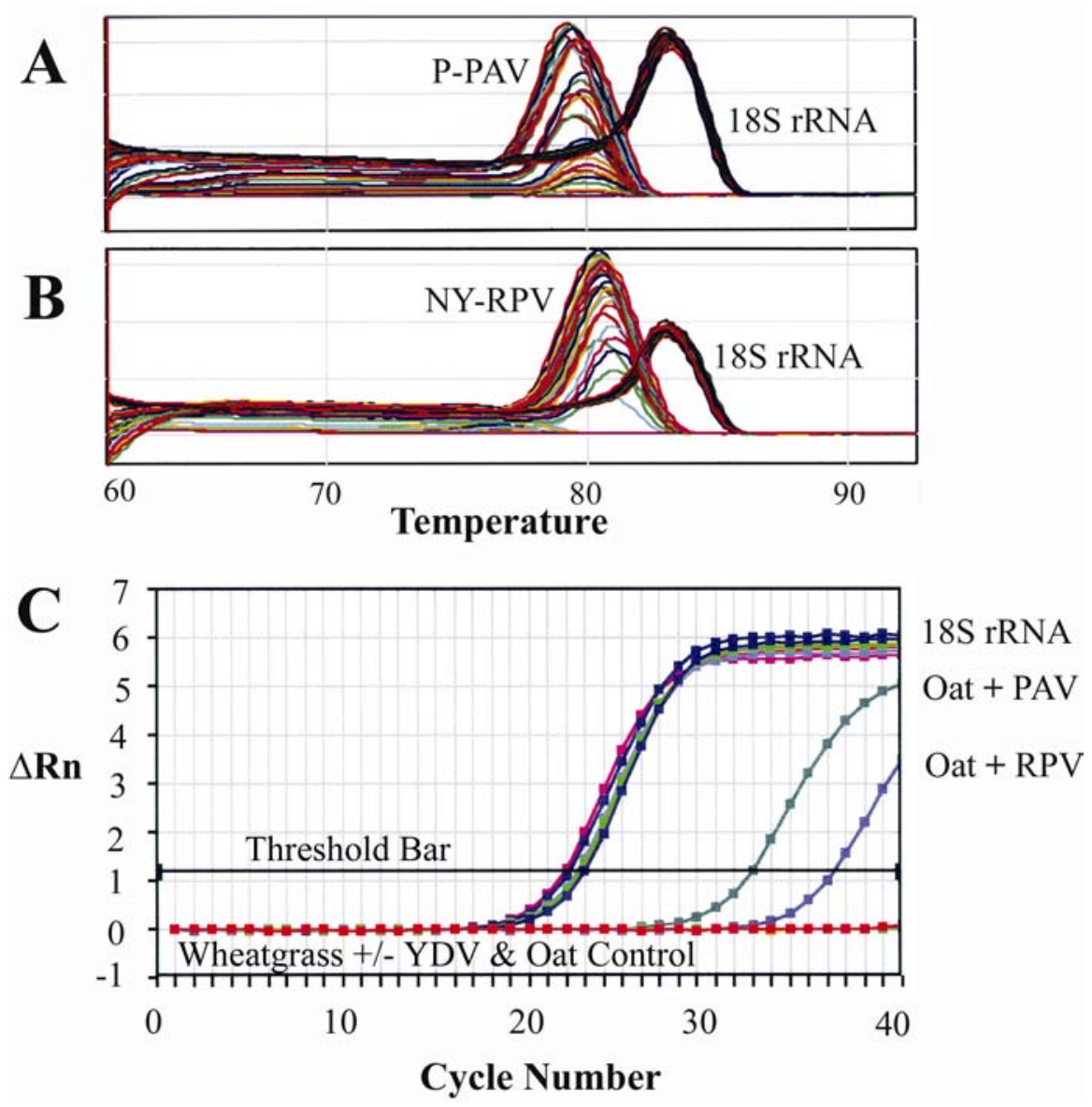

Fig. 2. Dissociation curve analysis of A, P-PAV and $18 \mathrm{~S}$ rRNA amplicons and B, NY-RPV and 18S rRNA amplicons in oat and wheatgrass produced from RNA isolated at different times after virus inoculation. All of the PAV, RPV, and $18 \mathrm{~S}$ rRNA dissociation curves are grouped at a common melting temperature ( $\left.T_{m}\right)$ for each amplicon, demonstrating that the same PAV, RPV, and 18S rRNA amplicon was produced in all of their respective polymerase chain reaction (PCRs)s. Equal loading of cDNA of all time points was shown by all of the 18S rRNA dissociation curves being grouped very closely together and having equal peak heights. The varying peak heights of the P-PAV and NY-RPV dissociation curves at their respective $T_{m}$ is due to the change in amounts of template viral RNA present at different times after inoculation. C, amplification plot of oat and wheatgrass with, or without, yellow dwarf virus. The dark horizontal line (threshold bar) shows the cycle threshold at an arbitrary point during the log phase of PCR amplification. 
powdery mildew, leaf rust, hessian fly (9), and green bug (8). To utilize this source of resistance, researchers crossed several wheatgrass species to wheat to obtain fungal- and virus-resistant wheat. In a previous report, Anderson et al. (2) showed by ELISA that a 7E/7D substitution line, P29, had a significant reduction in BYDV-P-PAV titer and no detectable CYDV-NY-RPV compared with the susceptible cv. Abe. In this study, we used the more sensitive method, Q-RT-PCR, to examine the temporal pattern of BYDV or CYDV accumulation in susceptible and resistant plants. As our model for resistant and susceptible plants, we chose the highly resistant wheatgrass Thinopyrum intermedium, a highly susceptible oat (cv. Clintland 64), a partially resistant wheat line (P29) that carries a single wheatgrass chromosome, and a susceptible wheat line, 8138.

Until now, ELISA has been used to detect and quantify BYDV and CYDV titers in plants. Although very useful, this assay does not have the level of sensitivity required to study the kinetics of BYDV or CYDV accumulation in plants following infestation with viruliferous aphids. RT-PCR is a sensitive alternative that can detect minute quantities of virus. Previously, Canning et al. (5) used RT-PCR to detect YDV in individual aphids and showed that the detection in that instance was below the threshold level of ELISA. RT-PCR, when combined with real-time kinetics to measure the quantity of the PCR product during amplification, has significantly improved sensitivity of virus detection and precision of quantification. Consequently, this method was used here to further our understanding of BYDV and CYDV accumulation in different hosts.

For wheatgrass, P-PAV and NY-RPV were not detectable by ELISA during the period of experiment. In oat, there was no appreciable PAV titer by ELISA until approximately 4 dpi. In contrast, real-time quantification indicated that replication starts as early as 2 hpi; P-PAV RNA accumulation reaches a plateau by $8 \mathrm{dpi}$ and then falls significantly by $12 \mathrm{dpi}$ (Table 3 ). One possible explanation could be that the viral RNA is being degraded by the plant as a defense mechanism through the viral-induced genesilencing pathway $(3,32)$. A second possible explanation is that there is a faster rate of plant growth relative to virus accumulation that would reduce the amount of virus RNA per unit of total RNA. However, ELISA indicates only a very slight reduction in the amount of PAV coat protein by 12 dpi (Table 2). This difference in ELISA and Q-RT-PCR data also was observed with NY-RPV, although a decrease in RPV RNA was not observed. However, a longer incubation time may have resulted in a decrease because this fluctuation over time in virus titer has been commonly observed for BYDV-MAV, BYDV-PAV, and CYDV-RPV $(24,30,33)$. Murphy and D'Arcy (19) showed that ELISA was an unreliable predictor of the yield of purified virus from different oat cultivars. This suggests that not all coat proteins are assembled into virions or that not all virions have encapsidated RNA. The lack of coordination of the viral RNA, coat protein, and virus purification data

$\mathbf{A}$

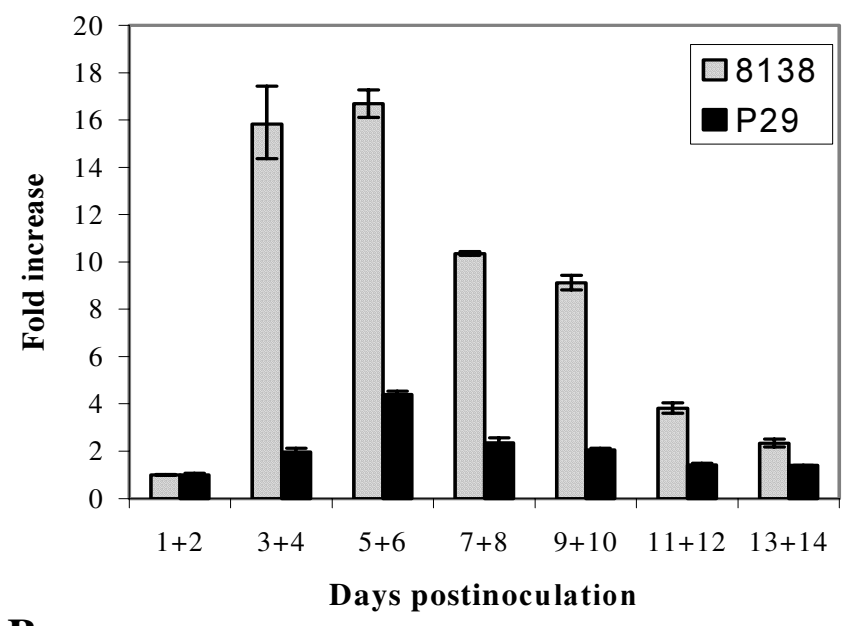

B

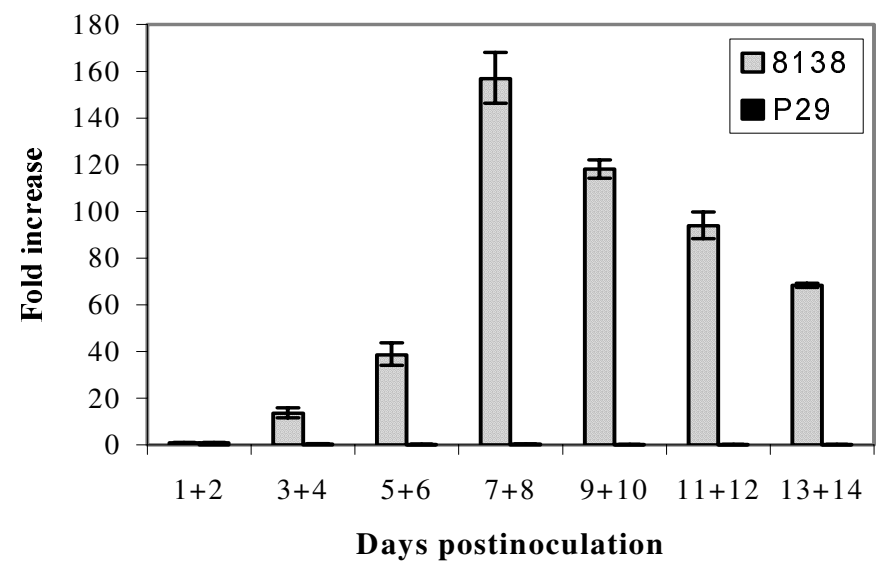

Fig. 3. Fold changes in accumulation of A, P-PAV RNA and B, NY-RPVRNA accumulation in resistant (P29) and susceptible (8138) wheat lines at days postinfestation (dpi) with viruliferous aphids. The relative quantity of PAV RNA was calculated using the comparative cycle threshold method. The control uninfested sample, collected directly after spraying with insecticide, was chosen as the calibrator and all other samples were quantified relative to it. 18S rRNA was used as an endogenous control to normalize the data for differences in input RNA between the various samples.

TABLE 3. Relative quantification of P-PAV and NY-RPV by real-time reverse-transcription polymerase chain reaction in oat and wheatgrass ${ }^{\mathrm{a}}$

\begin{tabular}{|c|c|c|c|c|}
\hline \multirow[b]{2}{*}{ Treatment $^{\mathrm{b}}$} & \multicolumn{2}{|c|}{ PAV } & \multicolumn{2}{|c|}{ RPV } \\
\hline & Oat & Wheatgrass & Oat & Wheatgrass \\
\hline \multicolumn{5}{|l|}{ Time } \\
\hline Control & ND & ND & ND & ND \\
\hline $2 \mathrm{~h}$ & $11.2(6.8-18.3)$ & $1.02(0.72-1.4)$ & ND & ND \\
\hline $4 \mathrm{~h}$ & $21.16(14-29)$ & $1.04(0.6-1.7)$ & $1(0.4-2.5)$ & ND \\
\hline $6 \mathrm{~h}$ & $32(19-52)$ & $1.04(0.9-1.3)$ & $4(1.8-9)$ & ND \\
\hline 4 days & $4,420(4,269-4,576)$ & $0.1(0.05-0.18)$ & $491.1(340-709)$ & ND \\
\hline 6 days & $9,195(7,573-11,165)$ & $0.08(0.06-0.11)$ & $1,746(1,618-1,884)$ & ND \\
\hline 8 days & $15,181(14,462-15,935)$ & $0.04(0.02-0.09)$ & $4,672(4,182-5,220)$ & ND \\
\hline 10 days & $12,854(11,268-14,664)$ & $0.13(0.09-0.21)$ & $9,216(8,599-9,877)$ & ND \\
\hline 12 days & $5,429(4,502-6,547)$ & $0.11(0.08-0.14)$ & $10,685(9,969-11,452)$ & ND \\
\hline
\end{tabular}

${ }^{\mathrm{a}}$ The point at which target gene amplification was first detected was set at 1 and samples at subsequent time points were quantified as fold difference in relation to this time point. The range of fold difference is given in parentheses; ND = no detection of target gene.

${ }^{\mathrm{b}}$ Time postinfestation; control $=$ no aphid. 
make it clear that additional research is required to understand the dynamics of BYDV replication.

In the experiment with susceptible wheat line 8138 and resistant wheat line P29, there were very large increases and subsequent decreases of both PAV and RPV in the susceptible wheat line (Fig. 3 ). The temporal pattern of PAV RNA accumulation was the same for P29 and 8138; however, there was significantly less PAV RNA in P29 compared with 8138 . Because previous data demonstrated that P29 was very resistant to RPV (2), in this experiment, an inoculation access period of $24 \mathrm{~h}$ with viruliferous aphids was used to allow the aphids to transmit as much virus as possible to the plant and ensure that NY-RPV was transmitted to P29. Short virus transmission periods, such as the 2 -h period in the wheatgrass and oat infestations, are sufficient to inoculate a plant with BYDV or CYDV; however, a longer virus transmission period, such as the $24 \mathrm{~h}$ used in the wheat experiment, increases transmission frequency (23). The results show, however, that in P29 the resistance to RPV is sufficiently strong that RPV RNA either could not be detected or was detected at very low levels throughout the experiment. Similar to the pattern in oat, increases in RPV RNA in wheat occurred after that of PAV. It is interesting that, in both oat and wheat, PAV replicated faster then RPV.

In Thinopyrum intermedium and P29, only very low amounts of NY-RPV RNA were detected, confirming the high level CYDVRPV resistance observed by Anderson et al. (2). Nevertheless, in the same study, it was shown that NY-RPV was able to replicate in mesophyll protoplasts of P29, suggesting that the CYDV-RPV resistance does not function at the single-cell level. It is possible, therefore, that the small amount of RPV RNA detected soon after inoculation was due to a low level of replication. However, more research is required to determine if RPV replication is occurring in this case. Although P-PAV RNA amounts in P29 were relatively low compared with the susceptible line, P29 is not as resistant to PAV as wheatgrass. From this study and previous data of Anderson et al. (2), it is apparent that the complete BYDV resistance in wheatgrass was not transferred to P29, indicating that additional loci are involved in BYDV-PAV resistance $(17,27,29)$.

Using real-time fluorescence RT-PCR, we were able to detect and quantify viral RNA in susceptible and resistant inoculated plants as early as $2 \mathrm{hpi}$ and show that BYDV and CYDV viral RNA accumulation differed both in concentration and over time. This method, therefore, will be invaluable for studying the dynamics of BYDV and CYDV replication and subgenomic RNA production. Linking these data with PAV and RPV resistance and generalized plant defense responses also will allow experimentation into the mechanism of the wheatgrass-derived YDV resistance.

\section{ACKNOWLEDGMENTS}

This work was supported by USDA-ARS CRIS project 3602-21220006-00D and SCA project 58-3602-2-152. Mention of a trademark, proprietary product, trade names, or commercial products in this article is solely for the purpose of providing scientific information; it does not constitute a guarantee, warranty, recommendation, or endorsement by the USDA and does not imply approval to the exclusion of other products that also may be suitable. Published as paper 17164, Purdue University Agricultural Research Program. We thank A. Platteter for her excellent technical skills.

\section{LITERATURE CITED}

1. Alkemar, G., Larsson, S. L., and Nygard, O. 2001. Probing the secondary structure of variable sequence V4 in 18S ribosomal RNA in intact ribosomes from wheat and mouse. NCBI Sequence submission for $18 \mathrm{~S}$ ribosomal RNA. NCBI, Bethesda, MD.

2. Anderson, J. M., Bucholtz, D. L., Greene, A. E., Francki, M. G., Gray, S. M., Sharma, H., Ohm, H. W., and Perry, K. L. 1998. Characterization of wheatgrass-derived barley yellow dwarf virus resistance in a wheat alien chromosome substitution line. Phytopathology 88:851-855.
3. Baulcombe, D. C. 1999. Fast forward genetics based on virus-induced gene silencing. Curr. Opin. Plant Biol. 2:109-113.

4. Burnett, P. A. (ed.) 1984. Barley yellow dwarf. Proceedings of the workshop. International Maize and Wheat Improvement Center (CIMMYT), Mexico, D.F.

5. Bustin, S. A. 2000. Absolute quantification of mRNA using real-time reverse transcription polymerase chain reaction assays. J. Mol. Endocrinol. 25:169-193.

6. Canning, E. S. G., Penrose, M. J., Barker, I., and Coates, D. 1996. Improved detection of barley yellow dwarf virus in single aphids using RT-PCR. J. Virol. Methods 56:191-197.

7. Clark, M. F., and Adams, A. N. 1977. Characteristics of the microplate method of enzyme-linked immunosorbent assay for the detection of plant viruses. J. Gen. Virol. 34:475-483.

8. Gill, B. S, Raupp, W. J., Sharma, H. C., Browder, L. E., Hatchett, J. H., Harvey, T. L., and Moseman, J. G. 1986. Resistance of Aegilops squarrosa to wheat leaf rust, wheat powdery mildew, greenbug and Hessian fly. Plant Dis. 70:553-557.

9. Gill, B. S., Sharma, H. C., Raupp, W. J., Browder, L. E., Hatchett, J. H., Harvey, T. L., Moseman, J. G., and Waines, J. G. 1985. Evaluation of Aegilops species for resistance to powdery mildew, leaf rust, Hessian fly and greenbug. Plant Dis. 69:314-316.

10. Gussow, D., and Clackson, T. 1989. Direct clone characterization from plaques and colonies by the polymerase chain reaction. Nucleic Acids Res. 17:4000.

11. Hammond, J., Lister, R. M., and Foster, J. E. 1983. Purification, identity and some properties of an isolate of barley yellow dwarf virus from Indiana. J. Gen. Virol. 64:667-676.

12. Heid, C. A., Stevens, J., Livak, K. J., and Williams, P. M. 1996. Real time quantitative PCR. Genome Res. 6:986-994.

13. Henson, J., and French, R. 1993. The polymerase chain reaction and plant disease diagnosis. Annu. Rev. Phytopathol. 143:369-373.

14. Larkin, P. J., Banks, P. M., Lagudah, E. S., Appels, R., Chen, X., Xin, Z., Ohm, H. W., and McIntosh, R. A. 1995. Disomic Thinopyrum intermedium addition lines in wheat with barley yellow dwarf virus resistance and with rust resistance. Genome 38:385-394.

15. Lister, R. M., and Rainieri, R. 1995. Distribution and economic importance of barley yellow dwarf virus. Pages 29-53 in: Barley Yellow Dwarf Virus: Forty Years of Progress. C. J. D'Arcy and P. A. Burnett, eds. The American Phytopathological Society, St. Paul, MN.

16. Livak, K. J., and Schmittgen, T. D. 2001. Analysis of relative gene expression data using real-time quantitative PCR and the $2^{-\Delta \Lambda \mathrm{Ct}}$ method. Methods 25:402-408.

17. McGuire, P. E., Zhong, G.-Y., Qualset, C. O., and Dvorak, J. 1995. Resistance to barley yellow dwarf virus disease in derivatives of crosses between hexaploid wheat and species of Lophopyrum (Triticeae, Poaceae). Plant Breed. 114:287-290.

18. McKenzie, D. J., McLean, M. A., Mukerji, S., and Green, M. 1997. Improved RNA extraction from woody plants for the detection of viral pathogens by reverse transcription-polymerase chain reaction. Plant Dis. $81: 222-226$.

19. Murphy, J. F., and D'Arcy, C. J. 1991. Enzyme linked immunosorbent assay: An unreliable predictor of yields of barley yellow dwarf viruses purified from three oat cultivars. Can. J. Plant Pathol. 13:332-335.

20. Nassuth, A., Pollari, E., Helmeczy, K., Stewart, S., and Kofalvi, S. A. 2000. Improved RNA extraction and one-tube RT-PCR assay for simultaneous detection of control plant RNA plus several viruses in plant extracts. J. Virol. Methods 90:37-49.

21. Patterson, F. L., Shaner, G. E., Foster, J. E., and Ohm, H. W. 1990. A historical perspective for the establishment of research goals for wheat improvement. J. Prod. Agric. 3:30-38.

22. Perry, K. L., Kolb, F. L., Sammons, B., Lawson, C., Cisar, G., and Ohm, H. 2000. Yield effects of Barley yellow dwarf virus in soft red winter wheat. Phytopathology 90:1043-1048.

23. Power, A. G., Seaman, A. J., and Gray, S. M. 1991. Aphid transmission of barley yellow dwarf virus: Inoculation access periods and epidemiological implications. Phytopathology 81:545-548.

24. Ranieri, R., Lister, R. M., and Burnett, P. A. 1993. Relationship between barley yellow dwarf virus titer and symptom expression in barley. Crop Sci. 33:968-973.

25. Rochow, W. F. 1979. Field variants of barley yellow dwarf virus: Detection and fluctuation during twenty years. Phytopathology 69:655660.

26. Rochow, W. F., and Carmichael, L. E. 1979. Specificity among barley yellow dwarf virus in enzyme immunosorbent assays. Virology 95:415420 .

27. Sharma, H. C., Gill, B. S., and Uyemoto, J. K. 1984. High levels of resistance in Agropyron species to barley yellow dwarf and wheat streak mosaic viruses. Phytopathol. Z. 110:143-147. 
28. Sharma, H. C., Ohm, H., Goulart, L., Lister, R., Appels, R., and Benlhabib, O. 1995. Introgression and characterization of barley yellow dwarf virus resistance from Thinopyrum intermedium into wheat. Genome 38:406-413.

29. Sharma, H. C., Ohm, H., and Perry, K. L. 1997. Registration of barley yellow dwarf virus resistant germplasm line, P29. Crop Sci. 37:10321033.

30. Skaria, M., Lister, R. M., Foster, J. E., and Shaner, G. 1985. Virus content as an index of symptomatic resistance to barley yellow dwarf virus in cereals. Phytopathology 75:212-216.

31. Vincent, J. R., Ueng, P. P., Lister, R. M., and Larkins, B. A. 1990. Nucleotide sequences of coat protein genes for three isolates of barley yellow dwarf virus and their relationships to other luteovirus coat protein sequences. J. Gen. Virol. 71:2791-2799.

32. Waterhouse, P. M., Graham, M. W., and Wang, M. B. 1998. Virus resistance and gene silencing in plants can be induced by simultaneous expression of sense and antisense RNA. Proc. Natl. Acad. Sci. USA 95:13959-13964.

33. Wen, F., Lister, R. M., and Fattouh, F. A. 1991. Cross-protection among strains of barley yellow dwarf virus. J. Gen. Virol. 72:791-799.

34. Zhang, Z. Y., Xin, Z. Y., and Larkin, P. J. 2001. Molecular characterization of a Thinopyrum intermedium Group 2 chromosome (2Ai-2) conferring resistance to barley yellow dwarf virus. Genome 44:11291135. 